\title{
THE SECESSION OF BANGLADESH IN INTERNATIONAL LAW: SETTING NEW STANDARDS?
}

\section{J. Castellino*}

\section{INTRODUCTION}

In the aftermath of the Second World War the victorious Allied Powers decided to set up a new system which was not built on indiscriminate use of force but, instead, encompassed values of peace and security that would bring order ${ }^{1}$ to a world racked by two World Wars in a time span of thirty years. This system, with the United Nations at its centre, has endured and today forms the basis of international law, governing the relations between states. Like the preceding League of Nations system, it has had to cope with numerous challenges which threatened its very foundations, but nevertheless its legitimacy has grown. In outlining the emergence of the state of Bangladesh as a crisis in the field of self-determination that challenged the rules of international law, this paper seeks to analyse how its resolution could be extrapolated as a stage in the development of the international law of self-determination. The relevance of this discourse to present-day issues is obvious. According to Thomas Franck we are faced with the phenomenon of 'post-modern tribalism'2 in an era of increasingly complex allegiances and choices of identity. ${ }^{3}$ Coping with the problem of self-determination, however broadly defined, is paramount to simultaneously maintaining the international legal order as well as fulfilling norms relating to human rights which are inspired by notions of justice. ${ }^{4}$ In a bid to fully understand the underlying issues at stake, it will be necessary to look at three other areas of international law affected by the crisis, besides the prime topic of secession. Accordingly this paper will also deal with other issues which are finely interwoven with, and inter-related to the issue of self-determination in the creation of Bangladesh, viz. the use of force, statehood and sovereignty, and recognition.

\footnotetext{
* University of Wolverhampton, England.

${ }^{1}$ See H.BULL, The anarchical society: a study of order in international politics (1995), especially chapter four.

${ }^{2}$ T.FRANCK, "Post-modern tribalism and the right to secession", in C.BrolmaNN et al. (eds.), Peoples and minorities in international law (1993) at 3.

${ }^{3}$ T.FRANCK, "Clan and super clan: loyalty, identity and community in law and practice", 90 AJIL (1996) 359.

${ }^{4}$ For a discussion about order versus justice, see A.MAZRUI, Cultural forces in world politics (1975).
}

Asian Yearbook of International Law, Volume 7 (Ko Swan Sik et al., eds.

๑ Kluwer Law International; printed in the Netherlands), pp. 83-104 
Our prime focus in this paper is on the questions raised by the secession of Bangladesh from the state of Pakistan, originally consisting of East Pakistan (Bengal) and West Pakistan (with the provinces of Punjab, Sindh, Baluchistan and the North West Frontier Province). The main hypothesis put forth is that secession can in some cases be considered a legitimate option within international law, particularly in the face of alleged genocide. The argument for preserving order is not thereby suddenly overturned. We shall rather try to demonstrate that preservation of an unjust order is sometimes not in the longer term interests of international peace and security. The Bangladesh case is also remarkable for the arguments it provides against the conceptualization of selfdetermination as limited to the salt-water ${ }^{5}$ type that held a central place in the decolonization process. It needs to be remembered that the Bangla nationalist movement repeatedly claimed that Bengal was being treated as a colony of Pakistan and that, therefore, it had a right to self-determination, distinct from the traditional form of emancipation of peoples from colonial rule. The relevance of these issues is obvious in view of the recent creation of a separate status for East Timor, as well as in light of other separatist movements currently fighting to achieve statehood. ${ }^{6}$

\section{SELF-DETERMINATION ${ }^{7}$}

\subsection{An evolving norm}

As mentioned elsewhere ${ }^{8}$ the self-determination movement gained momentum after the formulation of the UN Charter, ${ }^{9}$ with the active support of the Soviet Union. ${ }^{10}$ The United Nations Charter mentions the right of self-

\footnotetext{
${ }^{5}$ F.CAPOTORTI, Study on the rights of persons belonging to ethnic, religious and linguistic minorities (1977, UN Sales No.E.91.XIV.2); see also P.THORNBERRY, "Self-determination, minorities, human rights: a review of international instruments", 38 ICLQ (1989) 867 - 889.

${ }^{6}$ See A.HERACLIDES, "Seccesionist minorities and external involvement", 44 International Organization (1990) 341-378.

${ }^{7}$ For general reading, see I.BROWNLIE, Principles of public international law (1995); C.TOMUSCHAT, Modern law of self-determination (1994); D.J.HARRIS, Cases and materials on international law (1998); A.BUCHANAN, "Self-determination and the right to secede", 45 Journal of International Affairs (1992) 347; M. KOSKENNIEMI, "National self-determination today: problems of legal theory and practice", 43 ICLQ (1994) 241.

${ }^{8}$ See, inter alia, R.SUREDA, Evolution of the right to self-determination (1973); H.HANNUM, Autonomy, sovereignty and self-determination (1990); D.McGoLDRICK, The Human Rights Committee: its role in the development of the International Covenant for Civil and Political Rights (1991).

${ }^{9}$ In the modern context, self-determination traces its roots back to Roosevelt's Atlantic Charter of 1941. See S.P.SINHA, "Is self-determination passé?”, 12 Col.JTr.L (1973) 260; see also A.WHELAN, "Wilsonian self-determination and the Versailles settlement", 43 ICLQ (1990) 94; R.S.BAKER and W.E.DODDS (eds.), The public papers of Woodrow Wilson (6 vols., 1925-27).

${ }^{10}$ See A.CASSESE, "Right to self-determination", in L.HENKIN (ed.), The International Bill of
} 
determination among its objectives. ${ }^{11}$ As colonial regimes began to unravel, a norm of international law on the subject evolved that effectively put paid to colonial empires. It became the foundation for the development of the international law of human rights, ${ }^{12}$ based on the belief that, unless people had the freedom to determine their own political future, 'human rights' would be meaningless. By 1971, at the time of the Bangladesh crisis, the norm had developed into full-fledged international $\mathrm{law}^{13}$ in the strict context of the liberation of subjugated peoples from foreign domination. 'Foreign' was not defined, but in the United Nations context it referred specifically to the mechanism by which colonial peoples were to be freed from the white colonial domination. This had brought about the independence ${ }^{14}$ of India in 1947, despite the fact that its partition into Pakistan and India was not in keeping with another generally followed rule in the decolonization process thus far, that of uti possidetis. ${ }^{15}$ The international climate was also tempered by the failed Biafra secession from Nigeria, which had lead to fierce armed response while the international community held its breath and waited for the outcome of a civil war ${ }^{16}$, unable to pierce the veil of domestic jurisdiction guaranteed by Article 2 paragraph 7 of the United Nations Charter.

The problematic nature of self-determination was highlighted in the Biafran case by the clash of the conflicting norms on self-determination and territorial integrity. ${ }^{17}$ Since self-determination outside the colonial context would undoubtedly lead to disintegration, its application necessarily had to be restricted by the endorsement of values of international peace and security. ${ }^{18}$ The abortive Biafran secession strengthened the view that self-determination was to be strictly interpreted and applied only in the colonial context. ${ }^{19}$ The creation of numerous new states through the decolonization process was already a revolu-

Rights: The Covenant for Civil and Political Rights (1981). See also V.LENIN, Rights of nations (1947 edn).

${ }^{11}$ Article 1(2): “...to develop friendly relations among nations based on respect for the principle of equal rights and self-determination of peoples....".

${ }^{12}$ Article 1 of the International Bill of Human Rights (1966)

${ }^{13}$ See R.HIgGiNS, "UN and law making: political organs", 64 AJIL (1970) 43; also see R.EMERSON, "Self determination", in 65 AJIL (1971) 459; K.M.G.NAYAR, "Selfdetermination beyond the colonial context: Biafra in retrospect", in 10 Tex.ILJ (1975) 321.

${ }^{14}$ This term is used to mean the freeing of Indian domestic affairs from the British Crown.

${ }^{15}$ The norm of uti possidetis. See, generally, M.SHAw, "The heritage of states: the principle of uti possidetis juris today", 67 BYIL (1996) 75; also see S.RATNER, "Drawing a better line: uti possidetis and the borders of new states", 90 AJIL (1996) 590; K.H.KAIKOBAD, "Some observations on the doctrine of continuity and finality of boundaries", 49 BYIL (1983) 119.

${ }^{16}$ Biafra 1967-1970. See, generally, K.W.J.POST, "Is there a case for Biafra?", 44 International Affairs (1968) 26; see also NAYAR, loc.cit.n.13.

${ }^{17}$ See L.BRILMAYER, "Secession and self-determination: a territorial interpretation", 16 Yale JIL (1991) 177.

${ }^{18}$ For the conflict between territorial integrity and self determination, see R.HIGGINS, "Judge Dillard and the Western Sahara case", 23 Virg.JIL (1983) 187.

${ }^{19}$ NAYAR, loc.cit.n.13. 
tionary development in the international community of states and further fragmentation was not considered beneficial to international order. ${ }^{20}$ The creation of Bangladesh was, therefore, a direct challenge to international law. But the tide was strong enough for it to carry away some of the prevailing norms ${ }^{21} \mathrm{We}$ shall attempt to examine the impact of the case of Bangladesh on the law on self-determination.

\subsection{Bangla claim to statehood $^{22}$}

Fear of Hindu domination among the Muslim population of India forced the partition of the country. Backed by the two most densely populated Muslim areas of the subcontinent, the Muslim League expressed this sentiment as early as $1940^{23}$ by calling for the creation of a federal state with two 'separate and autonomous' wings at either end of the subcontinent. This dream was fulfilled in 1947 when India was divided with the two wings constituting themselves as a separate state of Pakistan, flanking the Indian state. The partition was against the grain of the uti possidetis ${ }^{24}$ principle according to which "to modify an established frontier would be quite unjustified", ${ }^{25}$ and, consequently, boundaries should not be changed on the departure of the colonial power. The norm was disregarded in the belief that the division into two major communities would be a safeguard for stability and order on the subcontinent, despite the problematic employment of religion as a criterion for the determination of statehood. The partition left various issues of Muslim-dominated communities such as Hyderabad, Kutch ${ }^{26}$ and Kashmir unresolved, ${ }^{27}$ but it went ahead, arguably in the in-

${ }^{20} \mathrm{ICJ}$ in Burkino Faso v. Mali, where the importance of order was reiterated. ICJ Rep.1986: 633.

${ }^{21}$ See also the 1970 Declaration on Principles of International Law Concerning Friendly Relations among States in Accordance with the Charter of the UN [UNGA res.2625 (XXV)], passed unanimously less than a year before the Bangladesh crisis.

${ }^{22}$ For a general reading see V.NANDA, "Self determination in international law: the tragic tale of two cities", 66 AJIL (1972) 321.

${ }^{23}$ Lahore resolution. See SISSON and ROSE, War and secession: Pakistan, India and the creation of Bangladesh (1990).

${ }^{24}$ See, generally, J.S.REEVES, "International boundaries", 38 AJIL (1944) 533; see also J.CASTELLINO, "Territory and identity in international law: the struggle for self-determination in the Western Sahara", 28 Millennium Journal of International Studies (1999) 523.

${ }^{25}$ Burkina Faso v.Mali, ICJ Rep.1986: 633.

${ }^{26}$ See Rann of Kutch case, 50 ILR 520.

${ }^{27}$ While the former two have been resolved, the issue of Kashmir remains a constant bugbear between the two states and has continued to negatively affect relations between them. It also needs to be borne in mind that the crisis arose in the decolonization period when state practice suggested that the norm of "nation-building" that KARL DEUTSCH spoke of (K.DEUTSCH and W.J.FOLTZ, Nation-Building, 1963) was paramount to the stability of the post-colonial state. The idea of division on grounds of religion or ethnicity may also have been abhorrent to the Allied Powers with their new plans for an international system, in light of the Nazi genocide of 
terest of the preservation of order and the regional peace and security on the Indian subcontinent and the surrounding parts of South Asia.

Another issue of note is that the salt-water model of self-determination was a once for all act. For India (and Pakistan), by expressing their will to be emancipated from British rule exercised and, in that process, also exhausted their right to self-determination. For the people of East Pakistan and other peoples of the Subcontinent ${ }^{28}$, however, it was merely one phase of selfdetermination. East Bengal had long felt treated like a colony of West Pakistan - a captive market for poor quality goods and a resource hot-bed for raw materials and foreign exchange. ${ }^{29}$ Besides, there had never been a fair representation of Easterners in the affairs of the Pakistani state, inducing them to reexamine their rights within the Union. With martial law lifted and elections called on the basis of universal suffrage,$^{30}$ Easterners hoped that their superior numbers would at last come to bear on the affairs of the state. ${ }^{31}$ But this hope remained unfulfilled, and the argument in most of the literature suggests that it was the high-handedness of General Yahya Khan and the West Pakistani politicians, followed by the punitive action of the Pakistan army, which prompted the call for outright independence ${ }^{32}$

\subsection{The merits of the Bangladeshi case ${ }^{33}$}

In light of the call for independence it is interesting to examine the claim of the Banglas to separate statehood and their right to self-determination. This will help illustrate the kinds of norms that have been used in state practice in the pursuit of statehood.

The Banglas have arguably always constituted a people 'different' from the West Pakistanis. Separated geographically by thousands of kilometres of Indian territory, the only features common to the two wings of Pakistan was Islam and the fear of being submerged by Hindu supremacy ${ }^{34}$ Geographic, historic, social and cultural factors suggest that the Banglas constitute a separate people ${ }^{35}$ within the meaning required for self-determination. As the rift between the two wings widened, and with victory in the general elections added to economic

\footnotetext{
Jews and other atrocities committed during World War Two.

${ }^{28}$ Notably peoples in Punjab, Kashmir, Hyderabad, Nagaland and Assam, and the Tamils and others in India and the Baluchis, Sindhis, Pukhtuns in Pakistan.

${ }^{29}$ From the jute trade. For a further elaboration of the economic factors see SISSON and ROSE, op.cit.n.23; T. FELDMAN, The end and the beginning (1975).

${ }^{30}$ SISSON and ROSE, op.cit.n.23 at 62.

${ }^{31}$ At the time of the 1970 elections East Pakistanis represented $56 \%$ of the total population.

${ }^{32}$ See A.MASCARENHAS, The rape of Bangladesh (1971).

${ }^{33}$ See NANDA, loc.cit.n.22.

${ }^{34}$ ROSE and SISSON, op.cit.n.23 at 46.

${ }^{35}$ See NANDA, loc.cit.n. 22 at 328.
} 
exploitation by West Pakistan, calls for autonomy gave way to demands for outright independence based on self-determination.

The geographic factor in the determination of the Banglas' separate peoplehood is of course highly significant. These factors have largely been ignored in the drawing of international boundaries in Africa, particularly in sub-Saharan Africa, ${ }^{36}$ but even there no state has been constituted with parts of its territory separated from each other by miles of foreign land. It could even be argued that Pakistan geographically resembled the old colonial empires in that its territory, while under one centre of control, consisted of several parts which were not attached to each other. The idea of labelling West Pakistan as the metropolitan state and East Pakistan as its overseas territory ${ }^{37}$, however, would of course be highly controversial since these terms had been used in relation to salt-water colonialism. Nonetheless authors writing about the secession of Bangladesh seem to suggest that this was the de facto situation. ${ }^{38}$

Other factors that need to be taken into account include historic, cultural and linguistic differences, all of which seem favourable towards the grant of peoplehood in international law to the Banglas, with a corresponding right to self-determination, apart from that exercised on their behalf by undivided India in achieving freedom from the British Crown. As far as the history of the region is concerned, East Bengal has never been linked in any way to what later became West Pakistan, except under British rule. ${ }^{39}$ Perhaps the issue that did clinch the matter for the Banglas was the linguistic differences which had the effect of mobilizing the population in their call for autonomy. This in spite of the fact that institutionalizing linguistic differences in the sub-continent is a dangerous undertaking due to the presence of nearly 200 different languages, besides dialects. It was a move which would predictably be resisted fiercely in the name of order.

That brings us to the action of the Pakistani army in curbing the separatist movement, which was labelled by some authors as 'genocide ${ }^{40}$ and which added to the resolve for self-determination and secession.

Besides challenging the norm of self-determination with respect to its scope, the act of secession was an affront to Pakistani sovereignty. Article 2(7) of the UN Charter gave the state of Pakistan the right to conduct its domestic affairs in a manner it saw fit without undue interference from the international community. The crisis in the eastern part of the country was an internal affair. This belief was bolstered by the events of the earlier Biafran crisis where the Nigerian army was allowed a free reign in asserting Nigerian sovereignty over

\footnotetext{
${ }^{36}$ See R.JACKSON, "Juridical statehood in sub-Saharan Africa', 46 Journal of International Affairs (1992) 1.

${ }^{37}$ Concepts used in UNGA res.1541 (XV) and SUREDA, op.cit.n.8.

${ }^{38}$ Notably ROSE and SISSON, op.cit.n.23, and MASCARENHAS, op.cit.n.32.

${ }^{39}$ See J.CASTELLINO, "Liberty, fraternity \& equality: the dubious fruits of 'National Selfdetermination in International Law', 1 Tuku Law Journal (1999) No.1: 1.

${ }^{40}$ Mascarenhas, op.cit.n.32, and SISSON and ROSE, op.cit.n.23.
} 
the break-away region of Biafra by way of a 'police action'. The international community was powerless to act, as it was in the Bangladesh case, as a result of the impasse in the Security Council due to the Cold War. ${ }^{41}$ However, unlike the Biafra insurgence, the Bangladesh crisis was decisively influenced by outside forces. In contravention of the basic norms of the UN Charter ${ }^{42}$ India employed military force to assist in the creation of the state of Bangladesh. What transpired in East Pakistan was plain third party intervention against a sovereign nation by aiding a separatist movement that sought to challenge the authority of the state to which it belonged. The fact that India and Pakistan did not enjoy a friendly relationship is a clear indication that political factors were most probably the prime motivators for the Indian action. We shall return to this theme later when dealing with the legitimacy of the Indian action in favour of self-determination.

\subsection{Evolution of the norm of self-determination after Bangladesh $^{43}$}

Although the right of the Banglas to independence is arguably justified, its achievement by armed intervention of a third state clearly challenges the foundations of international law. Should the law on self-determination be crystallized in accordance with the Bangladesh case, then several other cases would qualify for a solution that would definitely not be to the liking of certain actors of the international community. A typical example would be Kashmir, which has been the cause of two major wars ${ }^{44}$ and numerous skirmishes, ${ }^{45}$ and where a resolution along the lines of the Bangladesh case would see a reversal of the roles of the two main powers of the Subcontinent. The Kashmiri claim to independence is at least as strong as the Bangla one, the only notable difference being the geographic factors. In addition, the backing of Kashmiri 'terrorists' by Pakistani arms, ammunition and training, as alleged by India, are comparable to the overt and covert Indian logistic support for the separatist forces in $1971 .^{46}$ If Bangladesh could be legally established with Indian intervention, then Kashmir too could be formed with Pakistani intervention. This is perhaps the main reason why the international community as a whole, but particularly multi-ethnic states, are apprehensive about the self-determination principle. It

\footnotetext{
${ }^{41}$ For a discussion on the Security Council debates and arguments during the Bangladesh crisis, see HARRIS, op.cit.n.7 at 112 .

${ }^{42}$ Namely Art.2(4), which reads:" All members shall refrain in their international relations from the threat or use of force against the territorial integrity or political independence of any State, or in any other manner inconsistent with the purposes of the United Nations." See also Art.2(5).

${ }^{43}$ See BRILMAYER, loc.cit.n. 17.

${ }^{44}$ In 1948 and 1962 (besides the escalation of the 1971 war).

${ }^{45}$ Most recently in spring 1999, at Kargill. See http://www.india-web.com/goif.htm and http://www.pak.gov.pk/ for conflicting views on Kashmir.

${ }^{46}$ Mukhti Bahini and Mukhti Fauj, the two sections of the 'rebel' forces which gained Bangladesh its freedom with the aid of Indian arms and forces.
} 
would directly challenge the very foundation of the international system and undermine the maintenance of order which is among its prime aims.

The creation of Bangladesh demonstrates also the central problem in relation to secession - the question of exactly which entities deserve the right to self-determination ${ }^{47}$ and where the line can be appropriately drawn - a case in point in view of the Chittagong Hill Tribes' agitation seeking autonomy from Bangladesh. Inherent contradictions are unavoidably part of international law since no two situations are exactly similar and each case must be treated on its own merit. There is a reflection of this diversity in the Statute of the International Court of Justice and its Article 38 which lists the sources of international law that are available to the Court in determining on a dispute. Although there has been much debate within the academic community ${ }^{48}$ on the question as to whether these sources are to be explored in a hierarchical order, the fact that previous court rulings are listed in Article 38(1)(d) is a clear indication of the acceptance by the drafters of the diversity of situations. Besides, Article 59 of the Statute states that "The decision of the Court has no binding force except between the parties and in respect of that particular case".

Nevertheless, international law does seek to set out a system of rules by which international order can be maintained. These rules need to stand up to various situations, keeping in mind the existing diversity but at the same time acknowledging the possible similarities between these situations. In principle, therefore, if the constitution of the state of Bangladesh with the aid of Indian force is viewed as a case of self-determination, then the Kashmir issue might qualify for 'resolution' by similar actions by Pakistan.

\section{ARMED INTERVENTION BY A THIRD PARTY}

For the question about the legality of the Indian action in East Pakistan, it is necessary to start by examining customary law and state practice existing at the time leading up to the Bangla crisis. We shall briefly refer to the developments of the law of war and the attempts to ban the use of force prior to the UN Charter. This will be followed by a brief analysis of the situation under the Charter including its exceptional legitimation of the use of force in international relations. In analyzing the effect of these laws in the Bangladesh crisis we shall also examine the provisions of the Friendly Relations Declaration of $1970^{49}$ before attempting to identify the precedent, if any, that the Indian action has set.

\footnotetext{
${ }^{47}$ This dilemma was first enunciated by ROBERT LANSING, Secretary of State to WILSON in April, 1921. See I. JENNINGS, The approach to self-governance (1956) 55-56.

${ }^{48}$ See M.AKEHURST, "The hierarchy of the sources of international law", 47 BYIL (1974-5) 273.

${ }^{49} \mathrm{UNGA}$ res.2625(XXV).
} 


\subsection{The use of force prior to Bangladesh ${ }^{50}$}

The norms against the use of force have developed over the last few centuries $^{51}$ to a point where use of force to settle disputes is virtually outlawed today. Never before had an international framework been built around concepts of non-violence, since the right to wage war had always been considered a central right of the sovereign state. The concept of 'just war' traces its roots back to St. Augustine of Hippo and encompasses such figures as St. Thomas of Aquinas and others. ${ }^{52}$ Efforts in the aftermath of World War I to ban the use of force were resisted by the states who viewed war as an expression of their sovereignty. ${ }^{53}$ The system set up under the League was primarily based on the assumption that World War I had been a blunder and was stumbled upon rather than planned. While the system tried to outlaw the use of force it remained subject to the ultimate "right to take such action as they shall consider necessary for the maintenance of right and justice" in Article XV of the Covenant. ${ }^{54}$ Though the Briand-Kellogg Pact of $1928^{55}$ banned resort to force in relations between states, the major actors were able to find exceptions where they believed they could resort to force. The attempts failed to acknowledge reality as proved by the outbreak of yet another World War within fifteen years. The termination of that war and the creation of the UN and the Charter system saw the prohibition of the use of force begin to take on a more definitive shape.

The language of the two relevant Articles 2(4) and 51 of the UN Charter concerning the use of force ${ }^{56}$ has been debated amongst scholars with respect to questions such as whether there exists a right to anticipatory self-defence, ${ }^{57}$ and what constitutes 'action' by the Security Council. Yet, the crux of the issue is that the use of force is clearly outlawed with the sole exception of its exercise in self-defence. This was the law at the time leading up to the Bangladesh crisis. In reality states continued to resort to violence in pursuit of national interests, ${ }^{58}$ though justifying their actions with reference to Article 51 . One of the loopholes with the self-defence argument is that the notion of 'aggression' has

\footnotetext{
${ }^{50}$ For general reading on the use of force: I.BROWNLIE, International law and the use of force by states (1963).

${ }^{51}$ See I.BROWNLIE, "Use of force in self defence", 38 BYIL (1961).

${ }^{52}$ See H.MCCOUBREY and N.WHITE, International law and armed conflict (1992).

${ }^{53}$ See J.ElShTAIN, "Sovereignty, identity and sacrifice", 20 Millennium Journal of International Studies (1991) 395.

${ }^{54}$ Art.XV para. 7.

${ }^{55}$ General Treaty for the Renunciation of War, Paris 27 Aug.1928, 94 LNTS 57.

${ }^{56}$ The former calls on member states to refrain from the threat or use of force in their international relations while the latter acknowledges the right of self-defence - either individual or collective in the event of an 'armed attack'.

${ }^{57}$ As claimed by Israel for geo-strategic reasons. See T.FARER, "Israel's unlawful occupation", 82 Foreign Affairs (1991) 37.

${ }^{58}$ E.g. the UK in the Suez crisis. See D.FARNIE, East and West of the Suez: the Suez in history 1854-1956 (1969). As to the US in Haiti, see J.MORRIS, "Collective security and individual rights", in: Security issues in the post Cold War World (1996).
} 
never been satisfactorily defined so that judging the self-defence response always proves problematic. The UN Special Committee that met in 1973 to address the 'Question of Defining Aggression,"59 did so after the Bangladesh crisis and their definition was, moreover, never endorsed anyway due to its inherently problematic nature.

\subsection{Use of force and self-determination: the 1970 Declaration}

As mentioned earlier the 1970 Declaration on Principles of International Law Concerning Friendly Relations and Cooperation among States in Accordance with the UN Charter is highly significant since its statements are considered to express norms of customary international law. The Declaration states, inter alia, that "[e]very State has the duty to promote through joint and separate action, realisation of the principle of equal rights and self-determination of peoples ..." ${ }^{60}$ It also declares that every state must refrain from forcible action that deprives peoples of their right to self-determination, which is precisely how the Pakistani military action against the Banglas was viewed by India. However, while the 1970 Declaration is generally favourable to the Indian argument for intervention, this intervention was still in violation of the UN Charter which outlaws the use of force and interference in the domestic affairs of another state. ${ }^{61}$

We remain left with the question of the limits of the right to selfdetermination and the right to the use of force by third parties in support of self-determination movements. In recent years the term 'humanitarian intervention' has been increasingly used to justify (usually Security Council) action for the sake of international peace and security. In fact the UN practice of the early 1990s arguably poses a strong case in favour of collective intervention. Irrespective of the political nature of these interventions, the fact remains that they took place under the auspices of the Security Council (with the exception of the action in Kosovo in 1999) which has the right to take such action under the UN Charter. Thus whenever the Security Council intervenes in a selfdetermination struggle it is arguably legal if it takes place by way of enforcement action under Chapter VII. This in spite of the domestic sovereignty clause - Article 2(7) - since this particular article explicitly exempts Security Council action from its application. The question we deal with in the Bangladesh case, however, concerns action by a third party without a Security Council mandate. The Indian action was unilateral and went ahead despite attempts by the Secu-

59 B.FERENCZ, "Defining aggression - the last mile", 12 Col.JTr.L (1973), see also G.FITZMAURICE, "The definition of aggression", 1 ICLQ (1952).

${ }^{60}$ Loc.cit.n. 49 .

${ }^{61}$ It is to be noted that the Declaration has a saving clause to the effect that nothing in it should be taken as contrary to the provisions of the Charter (see General Part, sec.2 para.2). 
rity Council to block it. ${ }^{62}$ In light of the Charter-based system, it must be stated emphatically that the action was illegal. There is little justification in international law for a neighbouring country to forcefully determine the outcome of a domestic issue of a sovereign State.

This otherwise clear-cut norm became confused by the development, in the years immediately following the signing of the Charter, of the concept of human rights ${ }^{63}$ which began to erode the principle of domestic jurisdiction and to make the legitimacy of many state acts more questionable than before. ${ }^{64}$ Another factor that may have influenced the legality of the Indian action is the signing of the Genocide Convention in $1948 .^{65}$ In recognition of its abhorrent nature, genocide was declared to be a crime against humanity and states were obliged to prevent and punish it. While that is clear enough and would warrant some form of intervention, what remains unclear is whether the police action mounted by Pakistan and carried out by the Pakistani army, actually amounted to genocide within the meaning of the Convention.

\subsection{Indian action as self-defence}

The above arguments, though admittedly not indisputably tenable at the time of the crisis, were not referred to by the Indian government, who classified its use of force instead as an action of self-defence and, therefore, justified under Article 51 of the Charter. This article remains the favoured ground for states to justify the use of force beyond their international boundaries. India argued that the flow of refugees placed unbearable financial strains on the already impoverished regional economy of the Indian state of West Bengal. On this basis India claimed the right to take action in defence of its sovereignty to remedy the situation. Despite Indian attempts to bring the crisis under international attention, ${ }^{66}$ the international community was not prepared to become involved in the crisis and kept allowing Pakistan protection under the domestic affairs clause. The Indians had urged the international community to work towards a peaceful political solution by creating pre-conditions for the return of the refugees. ${ }^{67}$ Failure to heed this request was taken by India as leaving it no choice but to take unilateral action to safeguard its own security. Hence the Indian action in East Bengal was alleged to be taken in 'self-defence' 68 al-

\footnotetext{
${ }^{62}$ See HARRIS, op.cit.n.7 at 112 . No resolution was passed due to the Soviet defence of the Indian action. By using its veto power, the Soviet Union managed to stave off a Security Council resolution long enough for the Indian army to complete its action, thereby further highlighting the utility of the use of force.

${ }^{63}$ As strongly evidenced by the growth in human rights treaties, conventions and declarations.

${ }^{64}$ See B.SIMMA, The Charter of the United Nations. A Commentary (1994).

${ }^{65}$ The Convention on the Prevention and Punishment of the Crime of Genocide, 1948.

${ }^{66}$ See SISSON and ROSE, op.cit.n.23.

${ }^{67}$ See Mrs GANDHI's address to Parliament, 11 International Legal Materials (1972) 121.

${ }^{68}$ UN Charter Art.51.
} 
though, strictly legally speaking, no 'armed attack' had occurred that immediately threatened the Indian frontiers. The idea of economic threats giving rise to a right to self-defence was arguably not included in the Charter, casting serious doubt upon India's choice of this reason to justify its action.

On the other hand, if the spirit of the Charter is to be invoked it may be argued that the people of East Bengal had a right to self-defence which it exercised with the aid of the Indians. This argument would rest primarily on two grounds. First, Pakistan was legally constituted as a 'federal' state with two autonomous wings according to the 1940 Lahore Resolution. Without going into the intricacies of federalism, it does suggest that the eastern part of the country was to have a degree of autonomy which included an inherent right to self-defence of its own. This is a contentious statement but is backed up to some extent by Malcolm Shaw who argues that internal boundaries are nonviolable in case of dismemberment of a sovereign state. ${ }^{69}$ Its implication in the case of Bangladesh would suggest that the principle of uti possidetis translates into the creation of the new state within its original federal boundaries. Secondly, the UN Charter arguably recognizes a right to self-determination of all 'peoples ${ }^{, 70}$ and is opposed to genocide (as a crime directed toward a people) and to the use or threat of force within the international community - a point we shall return to later in this paper. The Pakistani use of force, though technically within the boundaries of the state, was nonetheless significant enough to affect the international community in terms of concern for humanitarian matters. These included the flow of refugees and the alleged commission of genocide, although the latter remains problematic as the question of whether the police action by the Pakistani military amounted to genocide is not generally accepted. ${ }^{71}$ However, if there were a risk of annihilation by an army intent on gaining control of a territory, there would need to be a right of self-defence for the threatened entity concerned under any form of law. What this paper seeks to suggest is that if we can protect the right of an individual to self-defence under municipal law and that of a State under international law, we ought to be able to justify also the right of a people to self-defence.

\footnotetext{
${ }^{69}$ M.N.SHAW "Self determination, autonomy and international boundaries", conference paper at the Symposium on Autonomy and Self Determination: Theories and Applications, held by the International and European Law Unit, University of Liverpool, and jointly organized by the Israel Colloquium and the S.P.T.L. International Law Group on the 27th of May, 1997. See also SHAw, loc.cit.n.15.

${ }^{70}$ UN Charter Art.1 para.2.

${ }^{71}$ Contrast, inter alia, SISSON and ROSE, op.cit.n.23, who do not admit the action as genocide despite pointing out its monstrosities, to MASCARENHAS, op.cit.n.32.
} 


\section{4. $\quad$ Precedents set $^{72}$}

The Indian army violated the territorial sovereignty of its neighbour in aiding a secessionist movement, raising the question of whether a state is allowed under international law to aid a self-determination movement against another state by direct use of force. This question is even more interesting if examined in light of the Biafran crisis that preceded events in Bangladesh, and in light of the current climate of UN-sponsored intervention on humanitarian grounds. It is true that the 1970 Declaration calls on UN member states to help peoples to realize their right to self-determination, but this was arguably aimed specifically at peoples subjugated to white colonial rule. This limitation, however, would be tenuous as it suggests different sets of rules to apply to similar situations.

The Banglas argued that East Pakistan was a colony of West Pakistan. ${ }^{73}$ This, coupled with legitimate autonomy demands drowned out, legally held elections annulled and a genocide-like campaign launched, arguably provided the Easterners the right to defend themselves by force. In order to succeed they enlisted the help and logistics of a foreign state. Thus the Indian aid would be justified and legitimized.

The (paradoxical) problem with this line of argument is that it could be held true for every self-determination movement irrespective of its merits. Separatist forces are as a rule at a disadvantage in fighting state mechanisms like armies and will, therefore, need aid from sympathetic states in their quest. Acceptance of such actions, however, would be contrary to the Charter-based values endorsed by the international community which is far more representative today than it was in $1945 .{ }^{74}$ Therefore, taking Bangladesh as a precedentsetting event would go against the will of that community.

\section{BANGLADESH AND STATE SOVEREIGNTY ${ }^{75}$}

\subsection{Internal matter of Pakistan - Applicability of Article 2(7) of the Charter}

State sovereignty is one of the basic pillars of the United Nations Charterbased system. ${ }^{76}$ The founders of the UN were wary of creating a form of world

\footnotetext{
${ }^{72}$ See J.CRAWFORD, "Criteria for statehood in international law", 48 BYIL (1976-77) 93 at 170.

${ }^{73}$ MASCARENHAS, op.cit.n.32, and NANDA, loc.cit.n.22.

${ }^{74}$ In terms of the sheer numbers of member states of the UN.

${ }^{75}$ See generally J.CAMILLERI and R.FALK (eds.), The end of sovereignty? The politics of a shrinking and fragmenting world (1992); C.CONSTANTINOU, "Before the summit: representations of sovereignty on the Himalayas", 27 Millennium Journal of International Studies (1998) 1; R.LAPIDOTH, "Sovereignty in transition", 45 Journal of International Affairs (1992) 325.

${ }^{76}$ See Preamble of the UN Charter.
} 
government that would supersede the state since it would not provide as good a form of system of representation as is provided by the state today. Besides, there was no proof that the international polity of states in fact desired a form of supra-national government, especially in light of its implications for state sovereignty. Instead, they created a system of international relations that recognized the overriding position of the states, regulating their behaviour in the international arena through a complex framework of rules centred around Article 2(7) of the Charter. This article is one of the vital cogs of the system and perhaps the most important of all the clauses of the United Nations Charter, laying down the right of a State to exercise exclusive sovereignty over its domestic affairs. It may be argued that without Article 2(7) few states would have endorsed the Charter since it would have allowed outside forces to decide on policy concerning issues within the states' jurisdiction, thereby putting smaller, less influential states at a significant disadvantage.

In the Bangladesh case the Pakistani government argued that the events leading up to the deployment of the army in East Pakistan were matters strictly within the internal jurisdiction of the Pakistani state and, consequently, it condemned the Indian attempts at internationalizing the matter as 'interference' and, therefore, illegal. The international community endorsed this view as the problem had basically arisen out of the 1970 elections and concerned a domestic political issue. The Pakistani government argued that the Banglas were trying to secede from the state of Pakistan with the help of India and that the victory of Mujib-Ur-Rehman in the 1970 elections was influenced by India. This claim, if proved, would place India on very weak ground in international law, since it would be up against Article 2(7), a clause that India herself had used many times in a bid to curb super-power interference. ${ }^{77}$

\subsection{Affecting 'international' peace and security}

One more angle that needs to be explored is whether the issue affected international peace and security since, if it did, the justification for outside 'interference/intervention' becomes stronger. From the Pakistani point of view, internationalization of the issue was the work of a hostile neighbour. What was at stake was a struggle for a constitutional system in the domestic politics of Pakistan without direct international implications. However, once the Pakistani army moved in to quell the separatist forces, and refugees fled across the frontier into India, the issue moved out of the realm of domestic politics, since it arguably pushed the unwanted population of Pakistan into Indian territory, thereby violating India's right to territorial sovereignty. However, it needs to be stressed that India did not have to accept the refugees. Pakistani sources argued that India in fact encouraged the refugee flow and then provided them

${ }^{77}$ See, for similar situations, Nicaragua v. US, ICJ Rep.1984; C.G.FENWICK, "Dominican Republic: international and collective self defence", 60 AJIL (1966) 64. 
with arms to fight against the sovereign Pakistani state. The facts indeed suggest that India does not always accept refugees. For example, it refused to take in fleeing Nepalese from Bhutan. Thus it was plausible that, in accepting refugees, India violated Article 2(7) by harbouring separatist forces that were out to destroy the foundations of a sovereign UN member state. This argument, however, breaks down when it comes to the refugee question in general, since it would suggest that all refugees are disruptive to the State from where they flee. This would go against the way in which international law has evolved with regard to the protection of refugees, in the pre- as well as in the post-Bangladesh period. Nevertheless, it does highlight the difficult nature of important questions such as where 'humanitarian aid' ends and where 'interference in domestic affairs' begins. Arguably, by the time the refugee flow thickened to nearly 10 million, the case was definitely affecting regional (especially India's), if not international, peace and security. It conferred an international dimension to the issue and pulled it away from the ambit of Article 2(7). ${ }^{78}$

\subsection{Right to police action}

When a peaceful settlement of the domestic conflict failed to materialize the Pakistani government decided to resort to force to curb the separatists. This was a sovereign act and cannot really be questioned within the sphere of international law since it concerned essentially a matter of domestic politics. After all, even an "imagined community" ${ }^{79}$ such as a state has an inherent right to protection under international law. Sending the army into certain parts of a state is not without precedent and has been used on numerous occasions by most countries in the world to quell domestic violence and protest. ${ }^{80}$ While in some cases the international community became outraged, the actions have always been considered as falling within the scope of Article 2(7) and, therefore, technically beyond the reach of international law per se. This was definitely true in Pakistan until, perhaps, the refugee flow began to affect the peace and security of India. It is instructive to view these developments through a postKosovar lens since the international community did 'pierce the veil' of Yugoslav sovereignty even without a Security Council mandate, in the name of human rights. This was, arguably, in contravention of international law since the action did not have the explicit permission of the sovereign state in question while affecting events within its territory. It may be argued that, apparently, a new norm is developing that sees the rights protected by Article 2(7) as being

\footnotetext{
${ }^{78}$ For a detailed analysis of how the flow began, see T.FELDMAN, The end and the beginning (1975).

${ }^{79}$ In the sense of B.Anderson, Imagined communities: reflections on the origin and spread of nationalism (1983).

${ }^{80}$ E.g. the Royal Ulster Constabulary in Northern Ireland, the Chinese security forces at Tianamen Square in Beijing, the Russian action in Chechnya.
} 
significantly weaker than in the past. But, while this might be true in Kosovo, it remains questionable in Chechnya.

To sum up, the international system is based on the premise that states are sovereign. The UN Charter protects the right of states to their sovereignty by separating their domestic and international affairs by way of a veil. Since the primary role and function of the United Nations as conceived at the time of the signing of the San Francisco Charter was the promotion of international peace and security, neither the UN nor any of its member states is allowed to interfere in the domestic affairs of any state unless by authority of a Security Council decision under Chapter VII of the UN Charter. However, once the veil is pierced as a result of the escalation of a domestic conflict beyond the boundaries of the state, the validity of Article 2(7) is limited. If the Charter would have functioned as it was meant to, India would have been able to request the Security Council for action in collective self-defence. Unhinged due to Cold War politics, however, the Security Council was unable to act. In this restricted light the actual Indian action was arguably lawful as an act of self-defence under Article 51 - as it was facing a threat to its peace and security. However, broadening the scenario by including the use of force by India and its instigation of the refugee flow for the purpose of destabilizing a hostile neighbour brings the case in direct confrontation with Article 2(7). It may thus be argued that classifying the Bangladesh incident, or even the recent action in Kosovo, as precedent-setting could sound the death knell for the system of states' inherent right to sovereignty over its domestic affairs. This would not only leave the state unprotected against separatist forces, but also vulnerable to (whether desirable or undesirable) forces from other states bent on influencing events to suit their national interests.

\section{RECOGNITION OF THE SOVEREIGN STATE OF BANGLADESH}

\subsection{Effects of recognition ${ }^{81}$}

India was the first country to recognize Bangladesh in December 1971, paving the way for further Indian assistance. The act of recognition was vital since it transformed the Awami League from a separatist movement to an aspiring international actor. Other states followed suit and within a year Bangladesh was accepted as a full-fledged international entity. ${ }^{82}$ Pakistani recognition of Bangladesh in 1976 and UN membership finally confirmed Bangladesh's status as a sovereign state.

The recognition of Bangladesh raised several interesting questions in the

\footnotetext{
${ }^{81}$ See J.DUGARD, Recognition and the United Nations (1987); H.LAUTERPACHT, Recognition in international law (1947); S.TALMON, Recognition of governments in international law (1997).

${ }^{82}$ By the end of February 1972, 31 countries had recognized the state of Bangladesh as a sovereign state.
} 
international legal discourse. Prime amongst these was whether the recognition of a state wipes out the issue of lawfulness of acts relating to its creation, or, in other words: does the fact of Bangladesh having become an undisputed actor at the international plane automatically render questions about the legality of its creation irrelevant? Or, does it simply mean that any contested claim attains legality as long as it is victorious. This question would perhaps ruefully be answered in the affirmative by Biafrans, but that would reduce the international system once more to one where the outcome of international conflict is primarily determined by the effectiveness of force. ${ }^{83}$

Another question that needs to be addressed relates to the point at which a struggle for secession becomes a cause that may be supported by another State. More specifically, what level of assistance is a UN member state entitled to provide against the sovereignty of another member state? Does recognition de facto confer legality upon a fledgling State ${ }^{84}$ These issues are extremely problematic and there are no clear answers forthcoming.

Next, there are two other important issues that need to be discussed with regard to the recognition of Bangladesh. First, the relevance of the Indian recognition to the unfolding of the crisis, and second, the impact of the timing of the recognition. As to the first issue the answer will have to be that the Indian recognition was a significant step in the emergence of the fledgling state. Gaining a strong supporter like India who was willing, after long covert support, ${ }^{85}$ to overtly endorse the cause of the new state in the international arena, undoubtedly facilitated the latter's further emancipation. Within a month of the Indian recognition Bhutan followed suit ${ }^{86}$ and by February 1972 thirty-one countries had recognized the state of Bangladesh. As for the second issue, early Indian recognition would most probably have been denounced by the international community. As has happened with the so-called Turkish Republic of Northern Cyprus, ${ }^{87}$ the international community usually avoids hasty recognition since it compromises the domestic jurisdiction of the state from which the entity in question is seceding. ${ }^{88}$ Early recognition of Bangladesh would definitely have been judged as undue interference in the internal affairs of Pakistan within the scope of Article 2(7). By early March, prior to the military action, the Awami League was the de facto government in the territory, ${ }^{89}$ demonstrating its effective control by a high-visibility, successful, civil disobedience

\footnotetext{
${ }^{83}$ See CRAWFORD, loc.cit.n.72 at 93.

${ }^{84}$ Ibid. at 99.

${ }^{85}$ See FELDMAN, op.cit.n.78 at 165 .

${ }^{86}$ Bhutan at the time was an associate state of India. Therefore, the Bhutanese support for Bangladesh was possibly influenced by Indian policy rather than inspired by any firm belief in the Bangla cause.

${ }^{87}$ See K.Chrysostomides, The Republic of Cyprus: a study in international law (2000); Z.M.NECATIGIL, Our republic in perspective (1985).

${ }^{88}$ See, however, the effect of early recognition of Croatia in 1991: S.STOJANOVIS, "The destruction of Yugoslavia", 19 Fordham Journal of International Law (1995) 337.

${ }^{89}$ See MASCARENHAS, op.cit.n. 32.
} 
movement. Yet recognition at that stage may still have been considered premature. Had the international community recognized the fact that at the time the reigns of government were already in the hands of the Awami League, exercising effective de facto control over the territory, it would have saved at least 3 million lives and prevented what was the worst refugee crisis of the time. However, the states were helpless owing to the veil of Article 2(7) that was still firmly in place. It appears legitimate to ask why 3 million people needed to be killed and a further 10 million displaced before the situation of mid-March re-occurred, this time to the satisfaction of an 'international community' with its limited will to see its resolution. The answer seems to be that in the interest of international order, peace and security it was the only way forward. The Biafra experience of only a few months earlier had reiterated the Hegelian concept of the nature of sovereignty: a nation can only mature into political manhood if it can successfully mobilize its people in its defence. ${ }^{90}$ Similarly, recent history suggests that, in general and notwithstanding exceptional cases like the international action in Kosovo, a separatist movement must defend itself successfully against adverse force, if it is to stake a claim to recognition as a state.

\subsection{Difference from Biafra}

The Biafran civil war remained a civil war for the prime reason that the Nigerian government was strong enough to subjugate the forces of separatism. This leads inevitably to the question of whether this in itself constitutes the defeat of the international system based on the outlawing of violence. The Biafran crisis was unique for the extent of indifference it drew from international institutions such as the Organization of African Unity (OAU) and the UN, with both entities merely watching nervously as the struggle unfolded. ${ }^{91}$ In the end, the superior arms of the Nigerian army prevailed and the Biafrans were shelved in history. This would suggest that there is a prima facie case for interference in independence struggles since without the aid of a strong enough army there seems to be little hope of victory. If recognition only comes after a 'successful' war of a nationalist liberation movement, then hopes of pacific settlement of disputes as well as humanitarian norms of representation and self-determination will be significantly compromised.

It has been argued that another important difference between Biafra and Bangladesh lay in the fact that the loss of East Pakistan did not really compromise the Pakistani state, while the loss of Biafra would have drained Nigeria of important resources. ${ }^{92}$ This is, at best, a problematic argument since according

\footnotetext{
${ }^{90}$ See ElSHTAIN, loc.cit.n.53 at 403.

${ }^{91}$ See H.HERACLIDES, Self-determination of minorities in international politics (1991) 1-60.

${ }^{92}$ This argument has also been advanced in the case of the Katanga secession from Congo. See G.J.LIBOIS, Katanga secession (1966).
} 
to the International Bill of Rights ${ }^{93}$ the right to self-determination encompasses the right of peoples to freely dispose of their wealth and natural resources. Besides, the argument is questionable also because there is no unanimity about the independence of West Pakistan from East Pakistani resources. ${ }^{94}$ Other arguments put forth have to do with geographic factors and issues of cultural proximity. Yet, all these factors pale in the face of the one decisive fact Bangladesh won the war of secession, while Biafra failed. This renders the international system's supposed values of anti-violence and pro-peace and security mere rhetoric.

\section{CONCLUSIONS}

After having examined the issues relating to the creation of the sovereign state of Bangladesh we are left with more questions than answers. One of these questions is whether the case constitutes a watershed in international law and international relations or whether it is merely an exception to the continued validity of a certain set of rules. Also pertinent is the question whether the case sets out a precedent for the legality of a state to assist break-away factions in another state in the name of self-determination. On the other hand, it must be acknowledged that special circumstances were involved in the Bangladeshi case and that the norm on self-determination is to be exercised restrictively so as not to allow every separatist movement take advantage at the cost of international order and peace and security.

A question that needs to be asked in light of the Bangladesh case is whether secession is lawful. This is a highly relevant question today in the face of an increasing number of instances of secessionist conflict. If the international legal system is to cope with these challenges, it will have to address this and other, subsidiary, questions. These would include the determination of the exact parameters of state sovereignty vis-à-vis the jurisdiction of international organizations and other collective security alliances such as NATO. There is also the much needed clarity with regard to the notion of 'humanitarian intervention' and its ability to pierce the veil of Article 2(7). The discourse would also need an answer to the question whether recognition as a new state erases the illegality involved in its creation and whether international approval should be the basis for the existence of a sovereign state. Finally, with regard to the comparison made between Biafra and Bangladesh and, more recently, between Chechnya and Kosovo, clear paradigms need to be established to enable identification of the exact nature of the conflict and to maintain consistency in deciding on whether or not to take international action.

In view of the available evidence, it is suggested that adopting Bangladesh as precedent-setting would upset the balance of the international system and

\footnotetext{
${ }^{93}$ See the joint Art.1 of the International Bill of Rights (ICCPR \& ICESCR) 1966.

${ }^{94}$ MASCARENHAS, op.cit.n.32, clearly sets out this argument.
} 
render the standards of peace, security and order difficult to maintain. Admittedly this raises the question of whether it is legally permissible to adopt rules without consistent applicability. Of course doubts like these can be resolved by an analysis of the political interests involved, but this arguably takes the issue out of the legal realm.

The above issues serve to highlight the complexities of international law, and demonstrate clearly the fallacy of incorporating simplistic 'realist' models into the realm of international law and politics that will not succumb to such straightjackets. ${ }^{95}$ We shall try to answer some of the questions raised, on the basis of the Bangladesh case, and thereby ascertain to what extent the international law of self-determination has been strengthened by the Bangladeshi secession.

First, it needs to be reiterated that Bangladesh is clearly an exception to the prevailing rule of self-determination. Under no circumstances could it be construed that the international community would generally allow states to be dismembered in the way that the formerly united Pakistan was. In framing a modern law of self-determination the need for order, being an inherent part of the UN Charter, will be an essential factor. On the other hand, our case study has very clearly demonstrated the inherent problems of rigid norms. A strong case can be made on the basis of evidence presented by some authors ${ }^{96}$ that the Bangla people were in many ways colonized by their counterparts in the western part of Pakistan. It was equally clear that they had very strong credentials for existence as a separate people, not only on the basis of linguistic, racial and cultural factors but also in terms of geography. Thus Bangladesh was clearly an exceptional case.

Second, it would be fallacious to extend this hypothesis and suggest that it would now be legal to assist breakaway factions in another state in the name of aiding self-determination. The Indian action in Bangladesh was clearly illegal in that it compromised Pakistani sovereignty. However, since this sovereignty was in dispute at the time by the Bangla claim to self-determination, the question of legality was clouded over. Although the case is not unique, nonetheless any suggestion according to which all separatist movements have a right to receive help from hostile third parties would, as pointed out earlier, lead to a breakdown in the Charter-based system. What isolates Bangladesh from other cases of secession is the fact that the Bangla people faced a Pakistani army that was allegedly indulging in genocide. On the sole account of the character of genocide as an international crime against humanity, it is argued here, could the Indian action be regarded legally justified. The Indian argument that the flow of refugees was affecting peace and security in the region, while valid as such, may be of limited value in that India had to obtain a Security Council mandate for their action which was in essence a pre-emptive first strike. Instead, what

\footnotetext{
${ }^{95}$ See M.KoSKENNIEMI, "International law in a post-realist era", 16 Australian Year Book of International Law (1995) 1.

${ }^{96}$ Notably MASCARENHAS, op.cit.n.32, and SISSON and ROSE, op.cit.n.23.
} 
actually transpired was a successful blockade of the Security Council option by India's ally - the Soviet Union - whilst the Indian army swiftly decided the argument by the use of force. There is little doubt to suggest that this was not how the drafters intended the system to work.

Third, arguments of economic colonialism would open up questions of international law that are even less defined than the areas examined in this paper. Undoubtedly, looking at these issues requires a holistic approach, including the inherent danger of generalizing the problem to an extent of escaping any kind of cogent symbiosis. Economic colonization, according to many developing world economists, is arguably exercised by the strong, western, states by exploiting the low technology and natural products produced by the poorer states. ${ }^{97}$ To consider this sufficient ground for violent self-determination and secession may be over-stretching the argument. Besides, within countries there will always be disparities in wealth distribution among different regions. While this is an avenue that is outside the scope of this paper, the Katanga secession would be an interesting case to look into these issues in more depth, as it had its causes to a large extent in the mineral wealth of the seceding region. The right to self-determination arguably - according to Article 1(3) of both International Human Rights Covenants - includes the right of peoples to freely dispose of their own natural wealth.

Fourth, there is the increasing trend towards further institutionalization of the factors contributing to peoplehood. During the decolonization period, peoplehood was easily granted to all communities that came under the guise of victims of white colonial rule. The parameters of the new post-colonial state were thus set by the colonial powers, including poorly drawn boundaries, and these thus became one of the first sources of differences among the new states. On the Indian subcontinent the process was almost immediately aggravated by the claim that religion too could be a constituting factor to statehood. The variety of factors taken as a ground to mount challenges against existing constitutional structures has steadily grown. The Katanga secession attempted to bring in natural resources as a means for legitimizing separatist claims, while Bangladesh was constituted by reference to linguistic differences. The Eritrean secession was achieved by mobilizing people along colonial historic grounds, and more recent separatist conflicts have been motivated by ethnic identity.

In an international system still geared towards the preservation of order, the increasing scope of controversies severely threatens the integrity of the system. But as can be seen from the Dayton Peace Agreement, it may be said that international law has acquiesced in trying to establish short-term order in the former Yugoslavia by re-costituting it along ethnic lines.

The main conclusion that we can draw from the case of Bangladesh is that in certain situations secession is a right under international law, functioning under the umbrella of self-defence as a general principle of law. ${ }^{98}$ The special

\footnotetext{
${ }^{97}$ See, generally, P.KENNEDY, Preparing for the twenty- first century (1992).

${ }^{98}$ As referred to in Art.38 para.1 item (c) of the Statute of the International Court of Justice.
} 
circumstance in the case was the alleged occurrence of genocide, and the creation of a new state as the only way available to stop it and to ensure the survival of the genus. 